\title{
Exfoliated Graphitic Carbon Nitride Nanosheets/Gold Nanoparticles/ Spherical Montmorillonite Ternary Porous Heterostructures for the Degradation of Organic Dyes
}

\author{
Peiqing Zhang, Fushuai Wang, Yawei Qin,* and Ning Wang* \\ Cite This: ACS Appl. Nano Mater. 2020, 3, 7847-7857 \\ Read Online
}

ACCESS | Lلll Metrics \& More | 国 Article Recommendations ｜ sl Supporting Information

ABSTRACT: Water-soluble organic carcinogenic pollutants have become a serious threat to both health and environment. Here, porous ternary spherical montmorillonite/exfoliated graphitic carbon nitride nanosheets/gold nanoparticles ( $\mathrm{SMt} / \mathrm{g}-\mathrm{C}_{3} \mathrm{~N}_{4} / \mathrm{Au}$ NPs) heterostructures were facile and green synthesized through a polydopamine chemistry method. These involved the coating of porous SMt with exfoliated $\mathrm{g}-\mathrm{C}_{3} \mathrm{~N}_{4}$ nanosheets and in situ growth of $\mathrm{Au}$ NPs. The prepared heterostructures exhibited a universal catalytic ability toward organic dyes, such as methylene blue (MB), rhodamine $6 \mathrm{G}$, and Congo red, in the presence of sodium

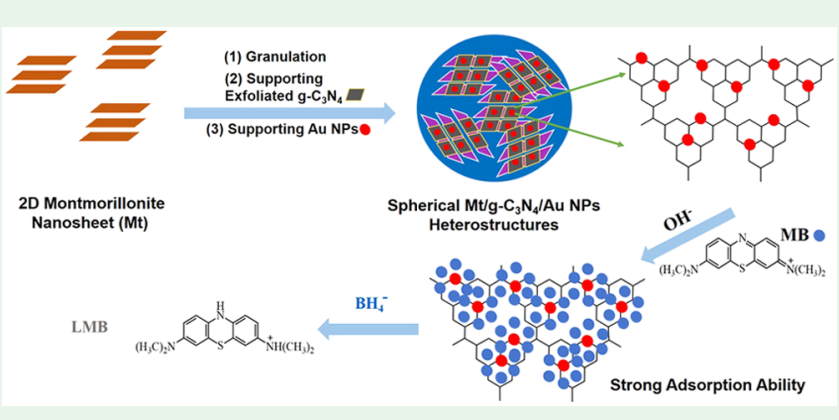
borohydride $\left(\mathrm{NaBH}_{4}\right)$. The catalytic activity would improve under high SMt/g- $\mathrm{C}_{3} \mathrm{~N}_{4} / \mathrm{Au}$ NPs concentration, high temperature, and high $\mathrm{pH}$ values. For example, the apparent reduction rate constant $\left(k_{\text {app }}\right)$ and turnover frequency (TOF) toward $\mathrm{MB}$ can reach $5.91 \mathrm{~min}^{-1}$ and $302 \mathrm{~h}^{-1}$, respectively, at $35{ }^{\circ} \mathrm{C}$ and $\mathrm{pH}$ values of 11 . Furthermore, the influences of the $\mathrm{pH}$ values on the catalytic performance were investigated, and the reason can be attributed to the strong enhanced adsorption capacity of SMt/g- $\mathrm{C}_{3} \mathrm{~N}_{4} / \mathrm{Au}$ NPs heterostructures toward organic dyes under the high $\mathrm{pH}$ values for facilitating electron transfer from $\mathrm{NaBH}_{4}$ to organic dyes. Moreover, the $\mathrm{SMt} / \mathrm{g}-\mathrm{C}_{3} \mathrm{~N}_{4} / \mathrm{Au} \mathrm{NPs}$ heterostructures were quite stable, being recycled at least 10 times with almost unchanged $k_{\text {app }}$. The excellent catalytic performance and recyclability recommend our synthesized SMt $/ \mathrm{g}-\mathrm{C}_{3} \mathrm{~N}_{4} / \mathrm{Au}$ NPs heterostructures for a wide range of applications in environment and wastewater treatment.

KEYWORDS: exfoliated $g$ - $C_{3} N_{4}$, gold nanoparticles, porous heterostructures, catalyst, organic dyes

\section{INTRODUCTION}

Multifunctional materials, especially hybrid nanomaterials, with a high diversity of structures and compositions, have attracted increasing attention because of their excellent properties, which are exploitable in various fields, such as catalysis, wastewater treatment, medicinal chemistry, and energy storage. $^{1-8}$ The rational control of dual or ternary heterostructures was achieved by applying a great number of approaches and strategies for their synthesis while using carbon oxide, ${ }^{9,10}$ carbonitride, ${ }^{11,12}$ silica oxide, ${ }^{13}$ and metal oxide $^{14}$ as supports for various active sites. Among them, graphitic carbon nitride $\left(\mathrm{g}-\mathrm{C}_{3} \mathrm{~N}_{4}\right)$, a fascinating $2 \mathrm{D}$ nanosheet semiconductor material with a graphite-like layer structure, is widely used as a catalytic support. With planar amino groups connected with tris-triazine in each layer and van der Waals forces between layers, it closely resembles graphene oxide. ${ }^{15}$ The $\mathrm{g}-\mathrm{C}_{3} \mathrm{~N}_{4}$ layer has a large surface area, providing a great number of active sites, favorable for enhancing the catalytic properties. $^{16}$

So far, bulk g- $\mathrm{C}_{3} \mathrm{~N}_{4}$ was usually prepared through thermal condensation of various carbon/nitrogen organic precursors. ${ }^{17-19}$ The g- $\mathrm{C}_{3} \mathrm{~N}_{4}$ nanosheets can be obtained from bulk g- $\mathrm{C}_{3} \mathrm{~N}_{4}$ by the liquid-phase exfoliation method in water, isopropyl alcohol, and $\mathrm{N}$-methylpyrrolidone and using ultrasound to accelerate the process. ${ }^{20}$ Loading metal and metal oxide nanoparticles on the surface of $\mathrm{g}-\mathrm{C}_{3} \mathrm{~N}_{4}$ nanosheets not only can enhance their performances but also allows them to enrich the portfolio of applications with new applications. ${ }^{21}$ However, although the theoretical surface area of $\mathrm{g}-\mathrm{C}_{3} \mathrm{~N}_{4}$ nanosheets is large, the exfoliated $\mathrm{g}-\mathrm{C}_{3} \mathrm{~N}_{4}$ nanosheets would reaggregate in the aqueous solutions because of low surface energy, heavily limiting the application of $g-\mathrm{C}_{3} \mathrm{~N}_{4}$ nanosheets in aqueous solution. ${ }^{22}$ Hence, it is greatly necessary to solve this issue to obtain advanced $\mathrm{g}_{-} \mathrm{C}_{3} \mathrm{~N}_{4}$ nanosheet-based multifunctional materials for practical applications.

Recently, nanoparticles or nanosheets such as $\mathrm{Pd},{ }^{23} \mathrm{TiO}_{2}{ }^{24}$ $\mathrm{CdS},{ }^{25}$ and $\mathrm{SnNb}_{2} \mathrm{O}_{6}{ }^{26}$ were mixed with $\mathrm{g}-\mathrm{C}_{3} \mathrm{~N}_{4}$ nanosheets to fabricate $\mathrm{g}-\mathrm{C}_{3} \mathrm{~N}_{4}$ nanosheet-based $0 \mathrm{D} / 2 \mathrm{D}, 1 \mathrm{D} / 2 \mathrm{D}$, and $2 \mathrm{D} /$

Received: May 18, 2020

Accepted: July 6, 2020

Published: July 6, 2020 
Scheme 1. Synthesis of 3D Porous SMt/g- $\mathrm{C}_{3} \mathrm{~N}_{4} / \mathrm{Au}$ NPs Heterostructures, Emphasizing the Three Main Processes, i.e., Granulation of Mt, Coating of $\mathrm{g}-\mathrm{C}_{3} \mathrm{~N}_{4}$, and Au NPs Loading

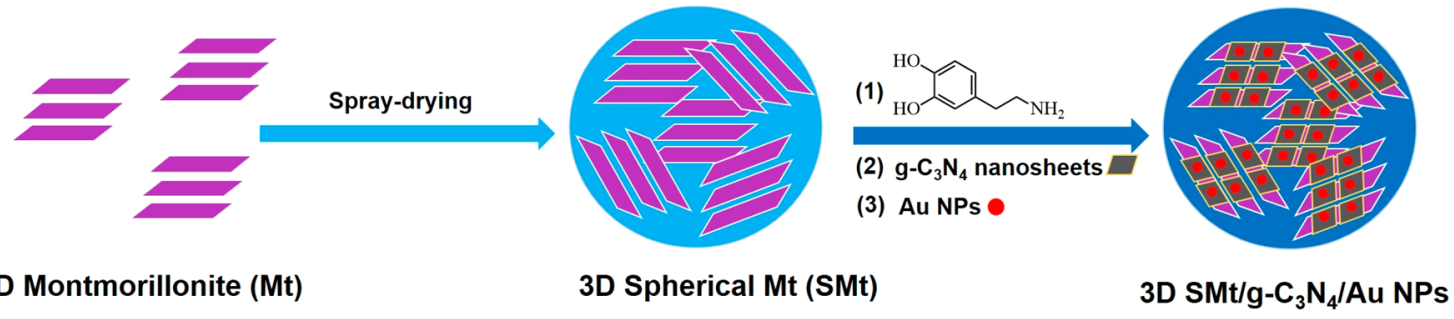

$2 \mathrm{D}$ heterostructures. In addition to the improved stability of g$\mathrm{C}_{3} \mathrm{~N}_{4}$ nanosheets, the high performances of the obtained materials were worth noting because of the synergistic effects of the two components of hybrid nanomaterials. Compared with $0 \mathrm{D} / 2 \mathrm{D}$ and $1 \mathrm{D} / 2 \mathrm{D}$ nanomaterials, $2 \mathrm{D} / 2 \mathrm{D}$ nanomaterials own a much larger surface area and more available catalytic active sites. For example, such a $2 \mathrm{D} / 2 \mathrm{D}$ heterostructure was synthesized by $\mathrm{Chen}$ et al. via the mixing of $\mathrm{SnNb}_{2} \mathrm{O}_{6}$ nanosheets with $\mathrm{g}-\mathrm{C}_{3} \mathrm{~N}_{4}$ nanosheets. The resulting nanomaterial exhibited a good catalytic performance toward the degradation of $\mathrm{MB} .^{27}$ However, compared with $\mathrm{g}-\mathrm{C}_{3} \mathrm{~N}_{4}$ nanosheets, the size of these nanosheets (nanosupports) is too small to wrap the $\mathrm{g}-\mathrm{C}_{3} \mathrm{~N}_{4}$ nanosheets. That is, a great amount of the $\mathrm{g}-\mathrm{C}_{3} \mathrm{~N}_{4}$ surface denudes in suspensions, which still have a great chance to link together, bringing a serious aggregation problem. Therefore, the selection of a suitable larger $2 \mathrm{D}$ substrate to support $\mathrm{g}-\mathrm{C}_{3} \mathrm{~N}_{4}$ nanosheets is a promising method to address this shortcoming.

Nanomaterials, such as carbon nanotubes and montmorillonite $(\mathrm{Mt})$, can form spherical 3D structures through spraydrying technology. ${ }^{28-30}$ The fabricated $3 \mathrm{D}$ porous structures can not only maintain the intrinsic properties of nanomaterials but also endow the materials with new properties such as large surface area, good flowability, and self-sedimentary capability, which are much more suitable as catalytic supports. Here, a 3D Mt stacked granule was selected as a support for $\mathrm{g}-\mathrm{C}_{3} \mathrm{~N}_{4}$ nanosheets, followed by the in situ growth of gold nanoparticles (Au NPs) on their surface through polydopamine chemistry. $\mathrm{Au}$ was chosen here because of its excellent electron-transfer ability. ${ }^{31}$ The organic pollutants, i.e., MB, Congo red, and rhodamine 6G, were selected as model molecules to evaluate the catalytic activity of the obtained material. The effects of the concentration of the catalyst, reaction temperatures, and $\mathrm{pH}$ values on the catalytic activity were further investigated, and the possible mechanism of catalytic activities depending on the $\mathrm{pH}$ values was proposed. Furthermore, the recyclability and stability of the catalyst were investigated. This work proposes a facile and effective strategy for producing porous heterostructures for a wide range of applications in the environment and wastewater treatment.

\section{MATERIALS AND METHODS}

2.1. Materials and Chemicals. Montmorillonite [Mt; $\left.(\mathrm{Na}, \mathrm{K}, \mathrm{Ca})_{0.33}\left(\mathrm{Al}_{1.67} \mathrm{Mg}_{0.33}\right) \mathrm{Si}_{4} \mathrm{O}_{10}(\mathrm{OH})_{2} \cdot n \mathrm{H}_{2} \mathrm{O}\right]$, dicyandiamide, chloroauric acid $\left(\mathrm{HAuCl}_{4}\right)$, dopamine hydrochloride, and sodium borohydride $\left(\mathrm{NaBH}_{4}\right)$ were purchased from Sinopharm Chemical Reagent Shanghai Co. Ltd., China. Tris. $\mathrm{HCl}$ buffer was received from Solarbio Science and Technology Co., Ltd., China. The organic dyes, methylene blue (MB), Congo red (CR), and rhodamine 6G (R6G) were obtained from Tianjin Guangfu Reagent Co., China. All of the chemicals and reagents were used as received without any further purification.
2.2. Fabrication of 3D Porous Spherical Montmorillonite (SMt)-Supported $\mathrm{g}-\mathrm{C}_{3} \mathrm{~N}_{4} / \mathrm{Au} \mathrm{NPs}$ Heterostructures. SMt was prepared using our previously reported method. ${ }^{29}$ The synthesis of g$\mathrm{C}_{3} \mathrm{~N}_{4}$ nanosheets was performed via calcination and ultrasonication from dicyandiamide. Typically, $10 \mathrm{~g}$ of dicyandiamide was introduced into a muffle furnace, and the temperature was raised to $550{ }^{\circ} \mathrm{C}$ within $4 \mathrm{~h}$. The organic was calcined at this temperature for $4 \mathrm{~h}$ to obtain bulk $\mathrm{g}-\mathrm{C}_{3} \mathrm{~N}_{4}$. Then, the cooled yellow bulk $\mathrm{g}-\mathrm{C}_{3} \mathrm{~N}_{4}$ was suspended in an aqueous/isopropyl alcohol (75/25 wt \%) mixed solvent to obtain a suspension with a solid concentration of $5 \mathrm{mg}$. $\mathrm{mL}^{-1}$. Then the suspension was subjected to an ultrasound treatment for at least $2 \mathrm{~h}$ using an ultrasonic cell disruptor at $25{ }^{\circ} \mathrm{C}$ to obtain a canary-yellow suspension. Pyridinedithioethylamine (PDA)-coated SMt prepared by our previously reported method ${ }^{29}$ was introduced to the canary-yellow suspension to obtain a mixture with a PDA-coated SMt concentration of $20 \mathrm{~g} \cdot \mathrm{L}^{-1}$. After being shaken for $6 \mathrm{~h}$, the product $\left(\mathrm{SMt} / \mathrm{g}-\mathrm{C}_{3} \mathrm{~N}_{4}\right)$ was washed at least five times, respectively, with deionized (DI) water and DI water containing $25 \mathrm{wt} \%$ isopropyl alcohol. SMt $/ \mathrm{g}-\mathrm{C}_{3} \mathrm{~N}_{4}$ was collected and dried at $60{ }^{\circ} \mathrm{C}$ in a vacuum oven for at least $12 \mathrm{~h}$ to a constant weight. Then SMt/g- $\mathrm{C}_{3} \mathrm{~N}_{4}$ was coated with PDA, and the process was the same with PDA-coated SMt. Then PDA-coated SMt $/ \mathrm{g}-\mathrm{C}_{3} \mathrm{~N}_{4}$ was added in an aqueous solution containing $50 \mathrm{~nm} \mathrm{HAuCl}_{4}$. In the dark, after rotating for $6 \mathrm{~h}$, the product was washed and dried like for the SMt/g- $\mathrm{C}_{3} \mathrm{~N}_{4}$ process above. For control, SMt/Au NPs catalysts were fabricated through a polydopamine chemistry method. ${ }^{29}$

2.3. Characterization. Fourier transform infrared (FT-IR) spectra were performed on a Nicolet iS50 Fourier transform infrared spectrometer (Thermo Electron Corp., United States) using $\mathrm{KBr}$ disks. The crystal structures of the synthesized samples were measured by X-ray diffraction (XRD; Bruker D8, Germany) using $\mathrm{Cu} \mathrm{K} \alpha$ radiation. The surface composition was examined by X-ray photoelectron spectroscopy (XPS; Thermo EscaLab 250Xi, United States) using Al $\mathrm{K} \alpha$ excitation. The morphology was analyzed by transmission electron microscopy (TEM; JEM-2200, Japan), coldfield-emission scanning electron microscopy (SEM; Jeol S4800, Japan), and atomic force microscopy (AFM; Multi-Mode 8, Veeco, United States). The content of Au NPs was measured by inductively coupled plasma mass spectrometry (ICP-MS, ELAN DRC II, PerkinElmer, Ltd., Hong Kong). The textural properties and $\zeta$ potential were examined by nitrogen physisorption (ASAP2020, Micromeritics, United States) and a Malvern Zetasizer (Nano ZS90, London, England), respectively.

2.4. Evaluation of the Catalytic Performances. The catalytic performances were evaluated in the catalytic reduction of organic dyes, i.e., $\mathrm{MB}, \mathrm{CR}$, and $\mathrm{R} 6 \mathrm{G}$, in the presence of $\mathrm{NaBH}_{4}$. The samples made of SMt/Au NPs (without g- $\mathrm{C}_{3} \mathrm{~N}_{4}$ nanosheets) were for control. The calibration curves were drawn for each model pollutant based on at least five concentrations (Figure S1). In a typical catalytic process, $20 \mathrm{mg}$ of a solid-state sample was added in $500 \mathrm{~mL}$ of an organic dye solution $\left(50 \mathrm{mg} \cdot \mathrm{L}^{-1}\right)$, and then $50 \mathrm{~mL}$ of an aqueous solution containing $0.1 \mathrm{M} \mathrm{NaBH}_{4}$ was added. The catalytic performances were examined based on the concentration of organic molecules before and after reactions evaluated by UV-vis spectrophotometry (PERSEE UT 1810, China). For the recycle experiments, after the reduction process was finished, the samples were separated from the mixture because of 

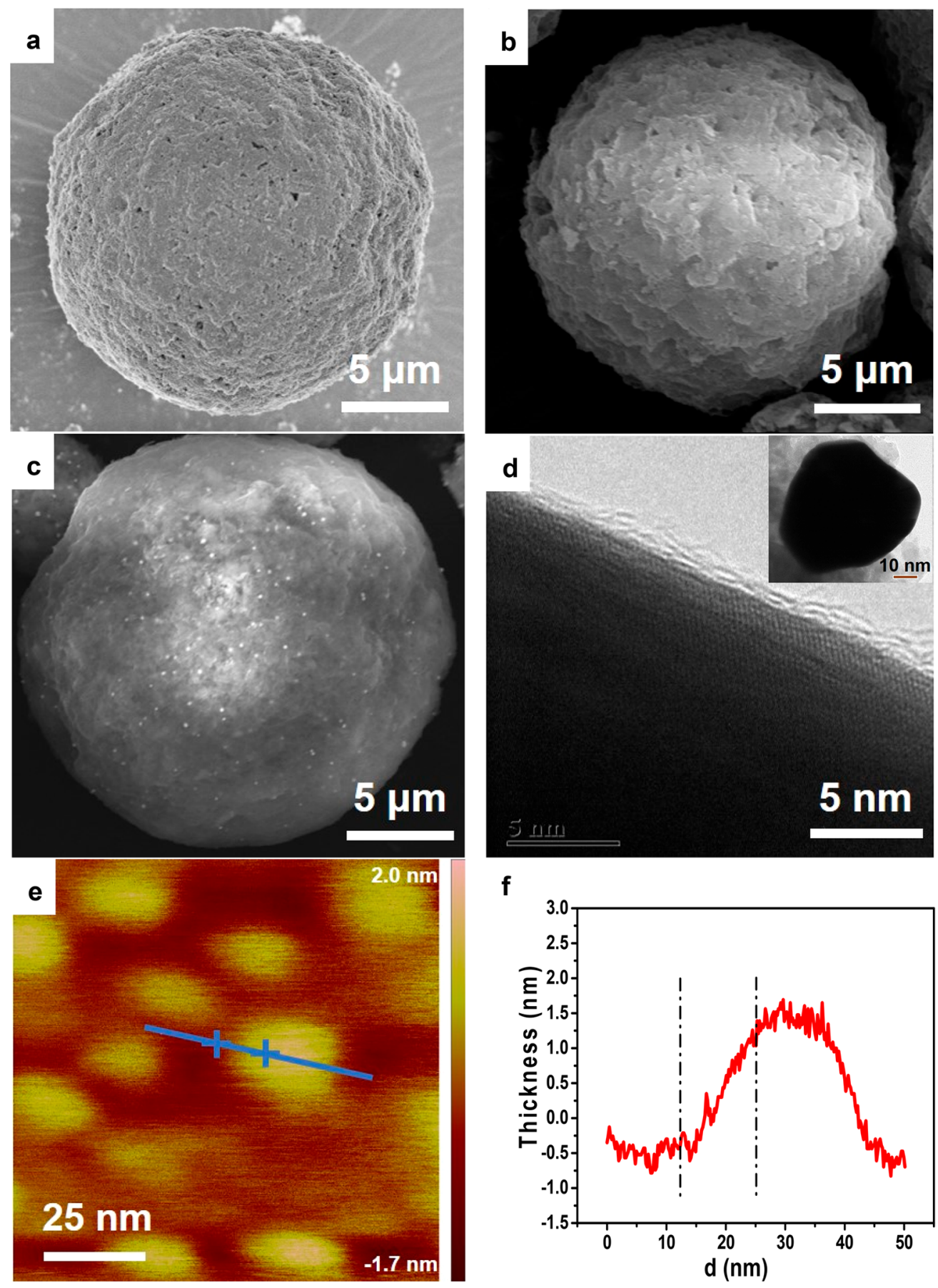

Figure 1. (a) SEM image of SMt. (b) SEM image of SMt coated with small g- $\mathrm{C}_{3} \mathrm{~N}_{4}$ nanosheets. (c) SEM image of SMt/g- $\mathrm{C}_{3} \mathrm{~N}_{4} / \mathrm{Au}$ NPs. (d) Highresolution TEM image of SMt//g- $\mathrm{C}_{3} \mathrm{~N}_{4}$. Inset: TEM image of SMt $/ \mathrm{g}-\mathrm{C}_{3} \mathrm{~N}_{4} / \mathrm{Au}$ NPs. (e and f) AFM image and corresponding thickness analysis of g- $\mathrm{C}_{3} \mathrm{~N}_{4}$ nanosheets.

the self-sedimentary property and reused consecutively for the next cycle. All of the reactions were in the dark.

2.5. Determination of the Point of Zero Charge (pHzpc). Typically, SMt $/ \mathrm{g}-\mathrm{C}_{3} \mathrm{~N}_{4} / \mathrm{Au}$ NPs samples were added to $10 \mathrm{~mL}$ of a $0.1 \mathrm{M} \mathrm{NaCl}$ aqueous solution to obtain a suspension with a solid concentration of $30 \mathrm{~g} \cdot \mathrm{L}^{-1}$. After adjustment of the $\mathrm{pH}$ values to 3,5 , $7,9,10$, and 11 , respectively, the solution was fully mixed using an MX-RL-Pro rotator at a speed of $50 \mathrm{rpm}$ for $24 \mathrm{~h}$. Two data graphs were drawn to understand the $\mathrm{pHzpc}$.

2.6. Adsorption Experiment. A total of $20 \mathrm{mg}$ of samples was added to a $100 \mathrm{~mL}$ aqueous solution containing $25 \mathrm{mg} \cdot \mathrm{L}^{-1}$ organic dyes. The UV-vis absorption spectra at different intervals were recorded to monitor the whole process. The removal percentage $(R)$ was obtained from the equation $R=\left(C_{0}-C_{\mathrm{t}}\right) / C_{0} \times 100 \%$, where $C_{0}$ and $C_{t}$ are the initial dye concentration and concentration of the reaction time, respectively.

\section{RESULTS AND DISCUSSION}

3.1. Synthesis of 3D Porous SMt/g- $C_{3} N_{4} / A u$ NPs Heterostructures. The main steps involved in the synthesis of $3 \mathrm{D}$ porous $\mathrm{SMt} / \mathrm{g}-\mathrm{C}_{3} \mathrm{~N}_{4} / \mathrm{Au} \mathrm{NPs}$ heterostructures are illustratively depicted in Scheme 1. First, the 2D Mt was dispersed in an ethanol solution, followed by a spray-drying technique to obtain a spherical 3D porous structure. Then, surface functionalization was performed with dopamine. 

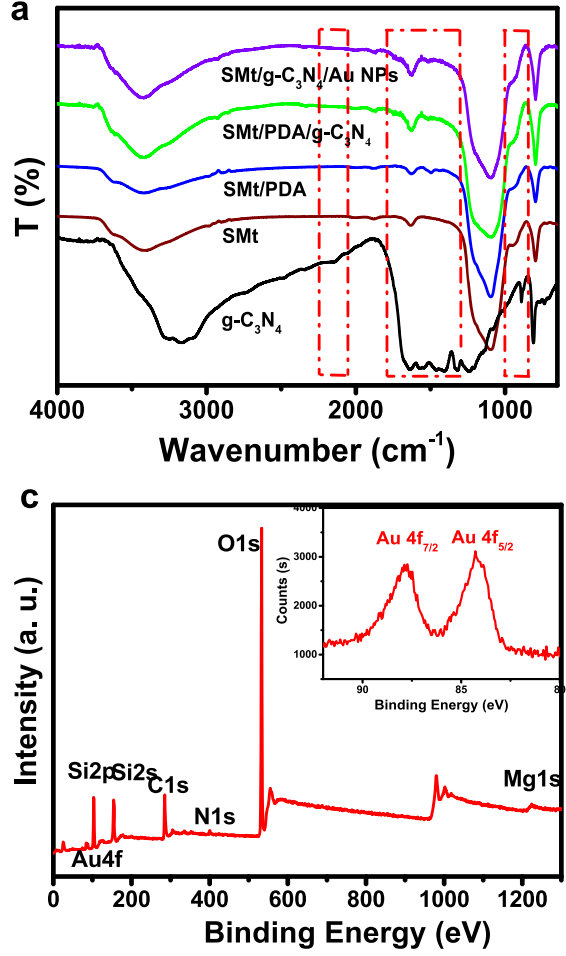

b

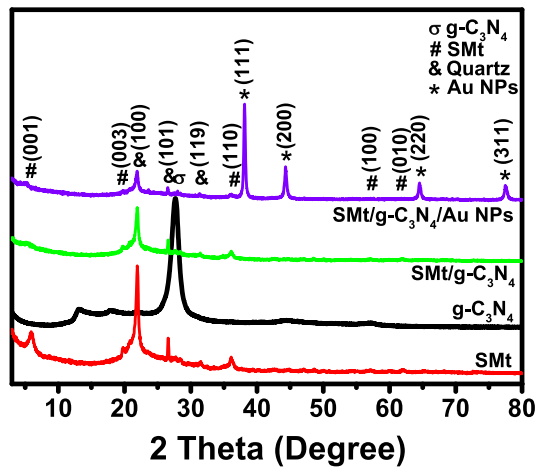

d

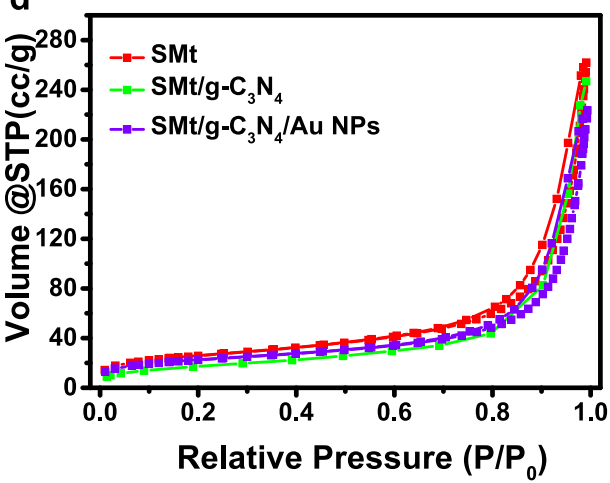

Figure 2. (a) FT-IR spectra and (b) XRD patterns of samples. (c) XPS spectrum of SMt $/ \mathrm{g}-\mathrm{C}_{3} \mathrm{~N}_{4} / \mathrm{Au}$ NPs. Inset: High-resolution XPS spectrum of $\mathrm{Au} 4 \mathrm{f}$. (d) $\mathrm{N}_{2}$ adsorption-desorption isotherms of samples.

Basically, the dopamine polymerized, generating polydopamine, whose role was to coat the surface of SMt and provide additional sites for the adsorption and reduction of $\mathrm{g}-\mathrm{C}_{3} \mathrm{~N}_{4}$ and $\mathrm{HAuCl}_{4}$, respectively. ${ }^{32-34}$

3.2. Morphological and Structural Studies. A controllable morphology with an improved regularity and particle size upon granulation is important for a reproducible surface functionalization and catalytic performance but also ensures an enhanced capability of recovery and reuse, as compared with the amorphous and nanosized pristine $\mathrm{Mt}^{29}$ The morphology of the samples was analyzed by SEM (Figure 1a-c), TEM (Figure 1d), and AFM (Figure 1e,f). Parts a-c of Figure 1 display the SEM images of the granulated $\mathrm{Mt}(\mathrm{SMt})$, SMt wrapped with small g- $\mathrm{C}_{3} \mathrm{~N}_{4}$ nanosheets $\left(\mathrm{SMt} / \mathrm{g}-\mathrm{C}_{3} \mathrm{~N}_{4}\right)$, and $\mathrm{Au}$ NPs loaded onto the surface of SMt $/ g-\mathrm{C}_{3} \mathrm{~N}_{4}$ through PDA chemistry ( $\mathrm{SMt} / \mathrm{g}-\mathrm{C}_{3} \mathrm{~N}_{4} / \mathrm{Au} \mathrm{NPs}$ ). It can be seen that these particles with sizes of about $20 \mu \mathrm{m}$ display similar spherical morphologies irrespective of the applied treatment. However, the surface of the particles shows several differences as a result of the treatment. Therefore, SMt displays a uniformly rough surface, whereas the PDA-modified $\mathrm{SMt} / \mathrm{g}-\mathrm{C}_{3} \mathrm{~N}_{4}$ surface presents multiple laminations because of the deposition of tiny exfoliated $\mathrm{g}-\mathrm{C}_{3} \mathrm{~N}_{4}$ nanosheets on the external surface. Parts $\mathrm{d}$ and e of Figure 1 show the TEM image of SMt/g- $\mathrm{C}_{3} \mathrm{~N}_{4}$ nanosheets and AFM image of $\mathrm{g}-\mathrm{C}_{3} \mathrm{~N}_{4}$ nanosheets, respectively. The TEM image shows close contact between $\mathrm{g}-\mathrm{C}_{3} \mathrm{~N}_{4}$ nanosheets and SMt, which is well consistent with the results of SEM. As observed from measurement of the AFM image (Figure 1f), the thickness of the $\mathrm{g}-\mathrm{C}_{3} \mathrm{~N}_{4}$ nanosheets is about $1.5 \mathrm{~nm}$. The black spots with a size of about $80 \mathrm{~nm}$ observed in the TEM image of SMt/g- $\mathrm{C}_{3} \mathrm{~N}_{4} / \mathrm{Au}$ NPs heterostructures are assigned to the Au NPs (inset of Figure 1d).

The chemical structures of SMt, g- $\mathrm{C}_{3} \mathrm{~N}_{4}$ nanosheets, PDAmodified SMt, SMt coated with $\mathrm{g}-\mathrm{C}_{3} \mathrm{~N}_{4}$ nanosheets, and SMt/ g- $\mathrm{C}_{3} \mathrm{~N}_{4} / \mathrm{Au}$ NPs were analyzed by FT-IR, as shown in Figure 2a. The spectrum of $g-\mathrm{C}_{3} \mathrm{~N}_{4}$ nanosheets displays a large band between 3000 and $3500 \mathrm{~cm}^{-1}$, which is assigned to the typical stretches of $\mathrm{N}-\mathrm{H}^{20}$ The band at $2150 \mathrm{~cm}^{-1}$ is characteristic of the stretching vibration of cyano terminal groups. The vibrational bands located between 900 and $1700 \mathrm{~cm}^{-1}$ are ascribed to the s-triazine derivatives. ${ }^{12}$ Clearly, these typical g$\mathrm{C}_{3} \mathrm{~N}_{4}$ peaks can be observed in the spectra of g- $\mathrm{C}_{3} \mathrm{~N}_{4}$-modified SMt samples, suggesting the good wrapping of $g-\mathrm{C}_{3} \mathrm{~N}_{4}$ nanosheets on the surface of SMt. In addition, the FT-IR spectrum of $\mathrm{SMt} / \mathrm{g}-\mathrm{C}_{3} \mathrm{~N}_{4} / \mathrm{Au} \mathrm{NPs}$ is very similar to that of $\mathrm{SMt} / \mathrm{g}-\mathrm{C}_{3} \mathrm{~N}_{4}$, indicating preservation of the SMt/g- $\mathrm{C}_{3} \mathrm{~N}_{4}$ structure after in situ growth of $\mathrm{Au} \mathrm{NPs}$ on its surface. Furthermore, the wrapping of $\mathrm{g}-\mathrm{C}_{3} \mathrm{~N}_{4}$ nanosheets on PDAmodified SMt was confirmed by the $\zeta$ potential. The obtained values for SMt, PDA-modified SMt, g- $C_{3} \mathrm{~N}_{4}, \mathrm{SMt} / \mathrm{g}-\mathrm{C}_{3} \mathrm{~N}_{4}$, and $\mathrm{SMt} / \mathrm{g}-\mathrm{C}_{3} \mathrm{~N}_{4} / \mathrm{Au} \mathrm{NPs}$ were $-42.2,-38.4,-29.2,-30.3$, and $-8.9 \mathrm{mV}$, respectively. The $\zeta$ potential of $\mathrm{SMt} / \mathrm{g}-\mathrm{C}_{3} \mathrm{~N}_{4}$ is very similar to that of $\mathrm{g}-\mathrm{C}_{3} \mathrm{~N}_{4}$, strongly demonstrating the coating of SMt with $\mathrm{g}-\mathrm{C}_{3} \mathrm{~N}_{4}$ nanosheets.

The samples were further analyzed by XRD, XPS, and $\mathrm{N}_{2}$ adsorption to assess their crystalline phases, surface chemical composition, and texture, respectively. Figure $2 \mathrm{~b}$ illustrates the XRD patterns of the samples. The diffractogram of $\mathrm{g}-\mathrm{C}_{3} \mathrm{~N}_{4}$ displays a strong typical diffraction peak at $27.7^{\circ}$. The XRD pattern of SMt $/ \mathrm{g}-\mathrm{C}_{3} \mathrm{~N}_{4} / \mathrm{Au} \mathrm{NPs}$ display, in addition to the peaks of $\mathrm{Mt}$ and $\mathrm{g}-\mathrm{C}_{3} \mathrm{~N}_{4}$, four new peaks at $38.1^{\circ}, 44.4^{\circ}, 64.4^{\circ}$, and $77.8^{\circ}$, corresponding to the (111), (200), (220), and (311) planes, respectively, of $\mathrm{Au}(0)$ (JCPDS 04-784). ${ }^{29}$ Remarkably, the intensity of $\mathrm{g}-\mathrm{C}_{3} \mathrm{~N}_{4}$ is decreased as a result of the exfoliation process. The surface chemical composition and oxidation states of elements in the SMt $/ \mathrm{g}-\mathrm{C}_{3} \mathrm{~N}_{4} / \mathrm{Au} \mathrm{NPs}$ heterostructure were analyzed by XPS, as shown in Figure $2 \mathrm{c}$. The XPS survey spectrum exhibits the peaks corresponding to 
$\mathrm{C}, \mathrm{Si}, \mathrm{N}, \mathrm{O}, \mathrm{Al}, \mathrm{Mg}$, and $\mathrm{Au}$, in well agreement with the chemical composition of bulk SMt/g- $\mathrm{C}_{3} \mathrm{~N}_{4} / \mathrm{Au}$ NPs heterostructures. As shown in the inset of Figure 1c, the highresolution XPS spectrum of Au $4 \mathrm{f}$ displays two peaks at 84.3 and $87.8 \mathrm{eV}$, which correspond to the binding energy of $\mathrm{Au}$ $4 \mathrm{f}_{7 / 2}$ and $\mathrm{Au} 4 \mathrm{f}_{5 / 2}$ of $\mathrm{Au}(0)$, confirming the existence of this element on the surface of the synthesized $\mathrm{SMt} / \mathrm{g}-\mathrm{C}_{3} \mathrm{~N}_{4} / \mathrm{Au}$ NPs heterostructure. ${ }^{9,34}$ The Au content was calculated as 2.7 wt $\%$ by ICP-MS, which is similar to the result reported otherwise. ${ }^{34}$ Considering the size of $\mathrm{Au} \mathrm{NPs}$ and the quite homogeneous dispersion on the surface of the composite (Figure 1c), this content is enough for the catalytic reduction of organic pollutants in wastewater. The pore structure and specific surface area were analyzed by $\mathrm{N}_{2}$ adsorption. As shown in Figure 2d, all of the samples exhibit isotherms of type IV with hysteresis of type IIb typical for slitlike mesopores. Compared with pristine $\mathrm{Mt}$ (Figure S3), the SMt, SMt/g$\mathrm{C}_{3} \mathrm{~N}_{4}$, and $\mathrm{SMt} / \mathrm{g}-\mathrm{C}_{3} \mathrm{~N}_{4} / \mathrm{Au}$ NPs samples showed a significantly increased pore volume and specific surface area (Table 1).

Table 1. Mesoscale Properties of Mt, SMt, SMt $/ \mathrm{g}-\mathrm{C}_{3} \mathrm{~N}_{4}$, and $\mathrm{SMt} / \mathrm{g}-\mathrm{C}_{3} \mathrm{~N}_{4} / \mathrm{Au} \mathrm{NPs}$

\begin{tabular}{lcc}
\multicolumn{1}{c}{ sample } & BET surface area $\left(\mathrm{m}^{2} \cdot \mathrm{g}^{-1}\right)$ & pore volume $\left(\mathrm{cm}^{3} \cdot \mathrm{g}^{-1}\right)$ \\
$\mathrm{Mt}$ & 7.9 & 0.10 \\
$\mathrm{SMt}$ & 60.2 & 0.36 \\
$\mathrm{SMt} / \mathrm{g}-\mathrm{C}_{3} \mathrm{~N}_{4}$ & 60.5 & 0.26 \\
$\mathrm{SMt} / \mathrm{g}-\mathrm{C}_{3} \mathrm{~N}_{4} / \mathrm{Au} \mathrm{NPs}$ & 52.1 & 0.22 \\
\hline
\end{tabular}

Above all, the stable structure of fabricated SMt $/ \mathrm{g}-\mathrm{C}_{3} \mathrm{~N}_{4} / \mathrm{Au}$ NPs via polydopamine chemistry can effectively enhance the electron-transfer capacity of Au NPs due to an increase in the local electron concentration through electron transfer from the g- $\mathrm{C}_{3} \mathrm{~N}_{4}$ nanosheets to $\mathrm{Au}$ NPs. Furthermore, the strong adsorption capacity of porous SMt and $\pi-\pi$ electron interaction of $\mathrm{g}-\mathrm{C}_{3} \mathrm{~N}_{4}$ nanosheets with organic dyes containing a benzene ring can significantly enhance the concentration of organic pollutant near the Au NPs, facilitating the uptake of electrons via organic pollutant. Hence, our synthesized SMt/g$\mathrm{C}_{3} \mathrm{~N}_{4} / \mathrm{Au}$ NPs heterostructures possess the character of abundant active sites, large specific surface area, and adsorption ability, indicating great potential in the fast catalytic reduction of organic pollution in wastewater.

3.3. Catalytic Properties of 3D Porous SMt/g- $\mathrm{C}_{3} \mathrm{~N}_{4} / \mathrm{Au}$ NPs Heterostructures. Au NPs supported on a conducting or semiconducting substrate can rapidly transfer electrons, which is significantly important for chemical catalytic reduction of organic pollutants in wastewater. ${ }^{9}$ Herein, g- $\mathrm{C}_{3} \mathrm{~N}_{4}$, a semiconducting material, was coated on PDA-modified SMt and used to load $\mathrm{Au}$ NPs. The high catalytic performance of the prepared heterostructure was first assessed in the degradation of several pollutants, among them, $\mathrm{MB}$, an organic pollutant with strong carcinogenicity. A very low concentration of $\mathrm{MB}$ in aqueous solution can alter the refractive index, greatly influencing the physiological activity of aquatic creatures. ${ }^{35}$ The catalytic reduction of $\mathrm{MB}$ in water was investigated using $\mathrm{NaBH}_{4}$ as a reduction agent. As shown in Figure 3a, the absorption peak of $\mathrm{MB}$ is placed at $665 \mathrm{~nm}$. After $1 \mathrm{~min}$ of reaction, the intensity of the peak decreased, and this decrease continued as the time was prolonged, so that no absorption was noticed after $5 \mathrm{~min}$ of reaction. As illustrated in Figure S4, the color of the $\mathrm{MB}$ solution changed from bright blue to colorless with the reaction time, indicating the catalytic reduction of carcinogenic $\mathrm{MB}$ to an inactive form, leucomethylene blue (LMB). ${ }^{28,36}$ The reaction rates of all three
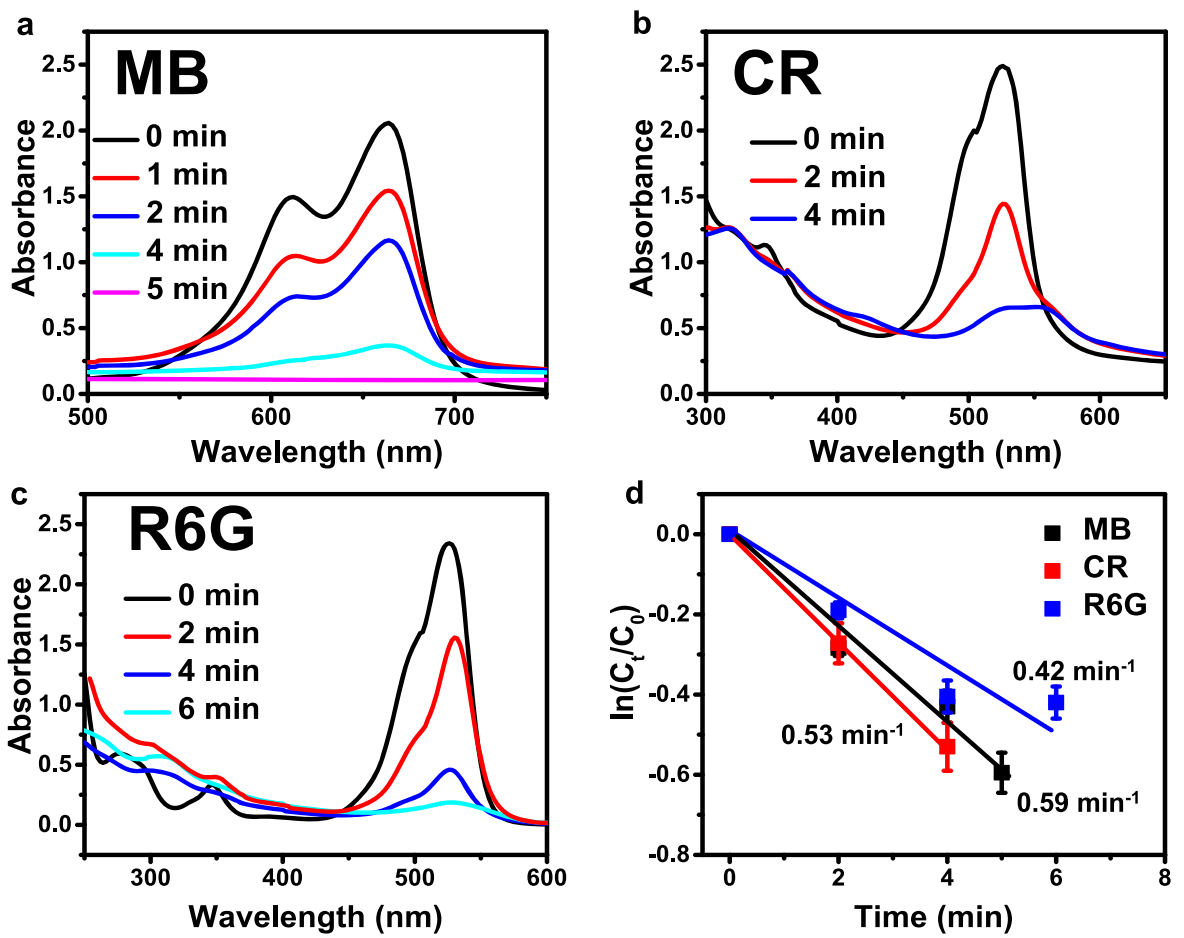

Figure 3. $(\mathrm{a}-\mathrm{c})$ Time-resolved UV-vis spectra of organic dyes. (d) Plot of $\ln \left(C_{t} / C_{0}\right)$ versus reaction time for the catalytic reduction of organic dyes. Reaction conditions: initial concentrations of organic dye $\left(25 \mathrm{mg} \cdot \mathrm{L}^{-1}\right), \mathrm{NaBH}_{4}(0.05 \mathrm{M})$, and SMt $/ \mathrm{g}-\mathrm{C}_{3} \mathrm{~N}_{4} / \mathrm{Au} \mathrm{NPs}\left(200 \mathrm{mg} \cdot \mathrm{L}^{-1}\right)$, $\mathrm{pH} 7, \mathrm{~T}=$ $25{ }^{\circ} \mathrm{C}$. 

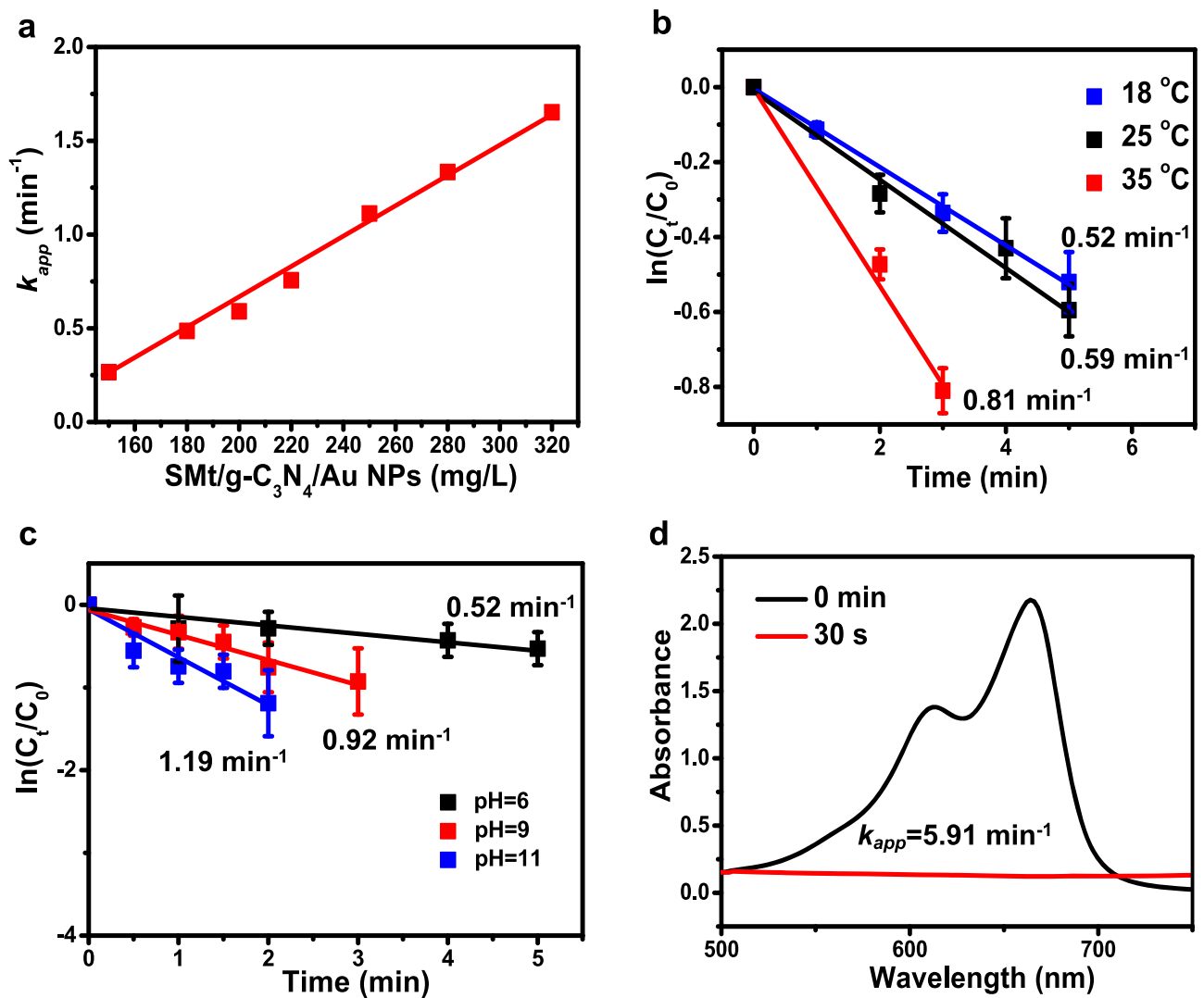

Figure 4. Effect of the (a) SMt/g- $\mathrm{C}_{3} \mathrm{~N}_{4} / \mathrm{Au}$ NPs concentration, (b) reaction temperature, and (c) $\mathrm{pH}$ values on the catalytic performance. (d) Time-resolved UV-vis spectra of $\mathrm{MB}$ organic dye. Reaction conditions: $25 \mathrm{mg} \cdot \mathrm{L}^{-1} \mathrm{MB}, 250 \mathrm{mg} \cdot \mathrm{L}^{-1} \mathrm{SMt} / \mathrm{g}-\mathrm{C}_{3} \mathrm{~N}_{4} / \mathrm{Au} \mathrm{NPs}$, $\mathrm{pH} 11$, and temperature $35^{\circ} \mathrm{C}$.

reduction reactions were obtained from the kinetic equation $\ln \left(C_{t} / C_{0}\right)=k_{\text {app }} t$ (Figure $3 \mathrm{~d}$ ), where the concentration of $C$ was obtained from the corresponding calibration curves (Figure S1). ${ }^{37}$ The reaction rate, $k_{\text {app }}$, is the slope of $\ln \left(C_{t} /\right.$ $C_{0}$ ) and the time $t$ curve. Good linearity was obtained for all three catalytic reactions, which implies pseudo-first-order kinetics. The experiment without $\mathrm{SMt} / \mathrm{g}-\mathrm{C}_{3} \mathrm{~N}_{4} / \mathrm{Au} \mathrm{NPs}$ heterostructures was carried out to highlight the catalytic role of the material. As shown in Figure S5, the absorbance of $\mathrm{MB}$ at $665 \mathrm{~nm}$ is almost unchanged. Besides, the experiments of SMt $/ \mathrm{g}-\mathrm{C}_{3} \mathrm{~N}_{4}$ heterostructures without Au NPs and only SMt were for control. As shown in Figures S6 and S7, after reactions of 5 and $6 \mathrm{~min}$, the absorbance value slightly decreased from 1.6 to 1.5 and from 1.5 to 1.4 for $\mathrm{SMt} / \mathrm{g}-\mathrm{C}_{3} \mathrm{~N}_{4}$ heterostructures and SMt, respectively. An obvious peak at $665 \mathrm{~nm}$ can be observed.

To prove the significant role of $\mathrm{g}-\mathrm{C}_{3} \mathrm{~N}_{4}$ nanosheets in the catalytic process, Au NPs-supported SMt (Au NPs concentration, 19.8 wt \%) without $\mathrm{g}-\mathrm{C}_{3} \mathrm{~N}_{4}$ nanosheets was prepared and used as a control. As shown in Figures S8 and S9, the catalytic reduction toward $\mathrm{MB}$ required $8 \mathrm{~min}$ to complete and the $k_{\text {app }}$ value was as low as $0.29 \mathrm{~min}^{-1}$. Considering the high $\mathrm{Au} \mathrm{NPs}$ concentration of the SMt/Au NPs catalyst, about 8 times higher than $\mathrm{SMt} / \mathrm{g}-\mathrm{C}_{3} \mathrm{~N}_{4} / \mathrm{Au} \mathrm{NPs}$ heterostructures, it can be affirmed that the heterostructures containing $\mathrm{g}-\mathrm{C}_{3} \mathrm{~N}_{4}$ nanosheets exhibited a much higher catalytic activity toward the MB model organic dye. It can be assumed that the high catalytic activity is significantly influenced by the $\mathrm{g}-\mathrm{C}_{3} \mathrm{~N}_{4}$ nanosheets. The g- $\mathrm{C}_{3} \mathrm{~N}_{4}$ nanosheets can adsorb organic dyes containing a benzene ring via $\pi-\pi$ electron interactions.
Furthermore, electron transfer from the $\mathrm{g}-\mathrm{C}_{3} \mathrm{~N}_{4}$ nanosheets to $\mathrm{Au}$ NPs occurs, increasing the local electron density for a facile uptake of electrons by the organic pollutants. ${ }^{13}$ These results demonstrate that the $\mathrm{SMt} / \mathrm{g}-\mathrm{C}_{3} \mathrm{~N}_{4} / \mathrm{Au}$ NPs heterostructures can indeed effectively catalyze the reduction of $\mathrm{MB}$ in the presence of $\mathrm{NaBH}_{4}$.

Other organic pollutants, $\mathrm{CR}$ and $\mathrm{R} 6 \mathrm{G}$, were selected to highlight the catalytic universality of the $\mathrm{SMt} / \mathrm{g}-\mathrm{C}_{3} \mathrm{~N}_{4} / \mathrm{Au} \mathrm{NPs}$ heterostructures. As shown in Figure $3 b, c$, the absorption peaks at 510 and $526 \mathrm{~nm}$, corresponding to CR and R6G, respectively, both decreased within 4 and $6 \mathrm{~min}$, respectively, in the presence of the catalyst and $\mathrm{NaBH}_{4}$.

Moreover, the effects of the concentration of catalyst, reaction temperature, and $\mathrm{pH}$ on the catalytic activities toward $\mathrm{MB}$ were investigated. As shown in Figure $4 \mathrm{a}$, the $k_{\text {app }}$ value of the $\mathrm{MB}$ reduction in the presence of $\mathrm{SMt} / \mathrm{g}-\mathrm{C}_{3} \mathrm{~N}_{4} / \mathrm{Au}$ NPs was linearly increased from 0.266 to $1.652 \mathrm{~min}^{-1}$ as the solid concentration increased from 140 to $320 \mathrm{mg} \cdot \mathrm{L}^{-1}$. Considered in our experiment, $\mathrm{NaBH}_{4}$ is excessive, and the increased $\mathrm{K}$ can be attributed to the increased catalytic area for electron transfer from $\mathrm{NaBH}_{4}$ to $\mathrm{MB}$. The influence of the reaction temperature on $k_{\text {app }}$ is depicted in Figure $4 \mathrm{~b}$. The value of $k_{\text {app }}$ increased from 0.52 to $0.81 \mathrm{~min}^{-1}$ as the temperature increased from 18 to $35{ }^{\circ} \mathrm{C}$.

The influence of the $\mathrm{pH}$ value on the reaction rates is depicted in Figure 4c. As was already discussed above, the degradation of organic dyes is based on electron transfer from the electron donor $\left(\mathrm{NaBH}_{4}\right)$ to the electron acceptor (organic dyes) using a catalyst as a "relay". However, this process is strongly influenced by the $\mathrm{pH}$. According to the empirical 
formula, $\log t_{1 / 2}=\mathrm{pH}-(0.034 T-1.92)$, where $t_{1 / 2}$ is the half-life and $T$ is the reaction temperature (expressed in Kelvin), the half-life of self-hydrolysis of $\mathrm{NaBH}_{4}$ in water increases from $0.36 \mathrm{~s}$ to 430 days as the $\mathrm{pH}$ value increases from 6 to $14 .^{38}$ Although the catalytic process is ended within a few minutes, a too fast self-hydrolysis of $\mathrm{NaBH}_{4}$ at low $\mathrm{pH}$ requires a high concentration of electron donor. Hence, the range of $\mathrm{pH}$ from 6 to 11 was selected for this work. As shown in Figure $4 \mathrm{c}$, the value of $k_{\text {app }}$ greatly increased from 0.52 to $5.91 \mathrm{~min}^{-1}$ as the $\mathrm{pH}$ value changed from 6 to 11. The experiments using $\mathrm{SMt} / \mathrm{g}-\mathrm{C}_{3} \mathrm{~N}_{4}$ without $\mathrm{Au} \mathrm{NPs}$ at different $\mathrm{pH}$ values were carried out for control. As shown in Figure $\mathrm{S} 10$, after reaction for $5 \mathrm{~min}$, the absorbance value decreased from 1.4 to 1.0 for $\mathrm{SMt} / \mathrm{g}-\mathrm{C}_{3} \mathrm{~N}_{4}$ heterostructures at $\mathrm{pH} 11$, which is similar to the result at $\mathrm{pH} 7$ (Figure S6). This result demonstrates that there is no change in the catalytic activity of $\mathrm{SMt} / \mathrm{g}-\mathrm{C}_{3} \mathrm{~N}_{4}$ under different $\mathrm{pH}$ values. All of these results revealed that the catalytic performance can be enhanced by controlling the concentration of $\mathrm{SMt} / \mathrm{g}-\mathrm{C}_{3} \mathrm{~N}_{4} / \mathrm{Au} \mathrm{NPs}$ heterostructures, reaction temperature, and $\mathrm{pH}$ value. As shown in Figure 4d, the catalytic process can be finished within $30 \mathrm{~s}$ and $k_{\text {app }}$ can reach $5.91 \mathrm{~min}^{-1}$ at a catalyst concentration of $250 \mathrm{mg} \cdot \mathrm{L}^{-1}$, a $\mathrm{pH}$ value of 11 , and a temperature of $35^{\circ} \mathrm{C}$, which is much higher than those reported for other systems, e.g., Au-based catalyst $\left(1.05 \mathrm{~min}^{-1}\right.$ for SMt and $1.80 \mathrm{~min}^{-1}$ for $\mathrm{Fe}_{3} \mathrm{O}_{4}$ and MgAlCe-LDH, respectively; Table 2). ${ }^{29,39,40}$ In

Table 2. Comparison of the Catalytic Performances of SMt/ g- $\mathrm{C}_{3} \mathrm{~N}_{4} / \mathrm{Au}$ NPs with Other Catalysts Reported in the Literature

\begin{tabular}{lcl}
\multicolumn{1}{c}{ catalyst } & $k_{\text {app }}\left(\mathrm{min}^{-1}\right)$ & \multicolumn{1}{c}{ ref } \\
$\mathrm{SMt} / \mathrm{g}-\mathrm{C}_{3} \mathrm{~N}_{4} / \mathrm{Au} \mathrm{NPs}$ & 5.91 & this work \\
$\mathrm{SMt} / \mathrm{Au} \mathrm{NPs}$ & 1.05 & 29 \\
$\mathrm{Fe}_{3} \mathrm{O}_{4} / \mathrm{Au} \mathrm{NPs}$ & 1.80 & 39 \\
$\mathrm{MgAlCe}-\mathrm{LDH} / \mathrm{Au} \mathrm{NPs}$ & 1.80 & 40 \\
\hline
\end{tabular}

addition, the TOF of the SMt/g- $\mathrm{C}_{3} \mathrm{~N}_{4} / \mathrm{Au}$ NPs heterostructures toward $\mathrm{MB}$ degradation was calculated as $302 \mathrm{~h}^{-1}$, according to the moles of $\mathrm{MB}$ catalytically reduced per mole of $\mathrm{Au}$ NPs, which is also much higher than that reported for SMt $\left(13.2 \mathrm{~h}^{-1}\right)$ and $\mathrm{Fe}_{3} \mathrm{O}_{4}\left(115 \mathrm{~h}^{-1}\right)$, demonstrating the high catalytic performance of the synthesized $3 \mathrm{D} \mathrm{SMt} / \mathrm{g}-\mathrm{C}_{3} \mathrm{~N}_{4} / \mathrm{Au}$ NPs heterostructures. ${ }^{29,39}$

3.4. Proposed Mechanism of the Catalytic Reaction Depending on the $\mathrm{pH}$. The influence of the $\mathrm{pH}$ value on $k_{\text {app }}$ is much greater than that of other parameters, which is supported by the considerable increase in $k_{\text {app }}$ as the $\mathrm{pH}$ increased from 6 to 11 . To understand the reaction mechanism at the molecular level, depending on the $\mathrm{pH}, \mathrm{MB}$ reduction was selected as the model reaction. The catalytic reduction of $\mathrm{MB}$ was performed in the presence of $\mathrm{NaBH}_{4}$ and a Au-based catalyst. It is well-known that the catalytic activity strongly depends on the number of active sites, that is, Au NPs. Under acidic or neutral conditions, $\mathrm{Au}$ ions can remain stable. However, $\mathrm{Au}$ NPs would release $\mathrm{Au}$ ions under alkaline conditions, which would locate near the surface of $\mathrm{Au} \mathrm{NPs}{ }^{41}$ ICP-MS was employed here to detect the release of $\mathrm{Au}$ ions in the solution at different $\mathrm{pH}$ values. The concentration of the $\mathrm{Au}$ ion at $\mathrm{pH} 7$ is $3 \mathrm{ppb}$, and the values were almost unchanged with increased $\mathrm{pH}$ values. On the other hand, the $\mathrm{pH}$ value would affect the adsorption behavior by changes of the charge density of the adsorbent and protonation state in the aqueous solution. ${ }^{16}$ As shown in Figure S11, the removal percentages (R) of $\mathrm{SMt} / \mathrm{g}-\mathrm{C}_{3} \mathrm{~N}_{4} / \mathrm{Au} \mathrm{NPs}$ heterostructures toward $\mathrm{MB}$ increased from $6 \%$ to $59 \%$ as the $\mathrm{pH}$ value increased from 4 to 11. It is worth noting that $R$ increased under alkaline conditions. Hence, the pHzpc was detected to reveal the dependence between the $\mathrm{pH}$ and adsorption profile. ${ }^{42}$ From Figure 5, the $\mathrm{pHzpc}$ is known as 7.02. At a solution $\mathrm{pH}$ value higher than 7.02, the surface of the $\mathrm{SMt} / \mathrm{g}-\mathrm{C}_{3} \mathrm{~N}_{4} / \mathrm{Au} \mathrm{NPs}$ heterostructures is negatively charged and strong electrostatic attraction would happen with a cationic dye, such as MB. ${ }^{43,44}$ Thus, a higher adsorption value was obtained at the high $\mathrm{pH}$ value. The high concentration of organic dyes near the heterostructures facilitates electron transfer from $\mathrm{NaBH}_{4}$ to organic dyes, leading to a remarkable increase in the apparent reduction rate constant $\left(k_{\text {app }}\right)$. For example, as shown in Figure $\mathrm{S} 12$, the blue color of the MB solution rapidly condenses the surface of the SMt/g- $\mathrm{C}_{3} \mathrm{~N}_{4} / \mathrm{Au}$ NPs heterostructures within $3 \mathrm{~s}$ and then instantaneously vanishes within $9 \mathrm{~s}$. The proposed mechanism of the catalytic reaction rate dependent on the $\mathrm{pH}$ values is shown in Figure 6.

3.5. Recyclability. Developing cost-effective catalysts is highly desirable for real applications. However, the cost of a catalyst is related to many factors, among them, the recyclability. To examine the ability of the prepared catalyst to be used for several cycles consecutively, the reduction of $\mathrm{MB}$ in the presence of SMt $/ \mathrm{g}-\mathrm{C}_{3} \mathrm{~N}_{4} / \mathrm{Au} \mathrm{NPs}$ was performed for 10 cycles (Figure $7 \mathrm{a}$ ). As can be seen, after 10 successive cycles, $k_{\text {app }}$ still remains above $90 \%$. This performance can be explained by the stability of $\mathrm{Au} \mathrm{NPs}$ and $\mathrm{g}-\mathrm{C}_{3} \mathrm{~N}_{4}$ nanosheets
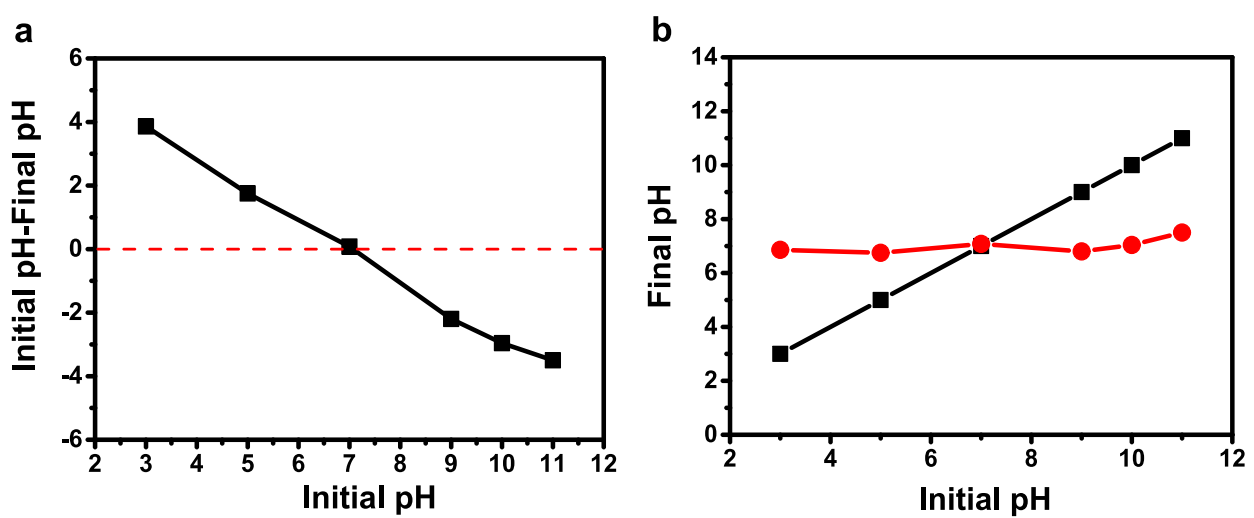

Figure 5. pHzpc determination of the SMt/g- $\mathrm{C}_{3} \mathrm{~N}_{4} / \mathrm{Au}$ NPs heterostructures by two different plots. 


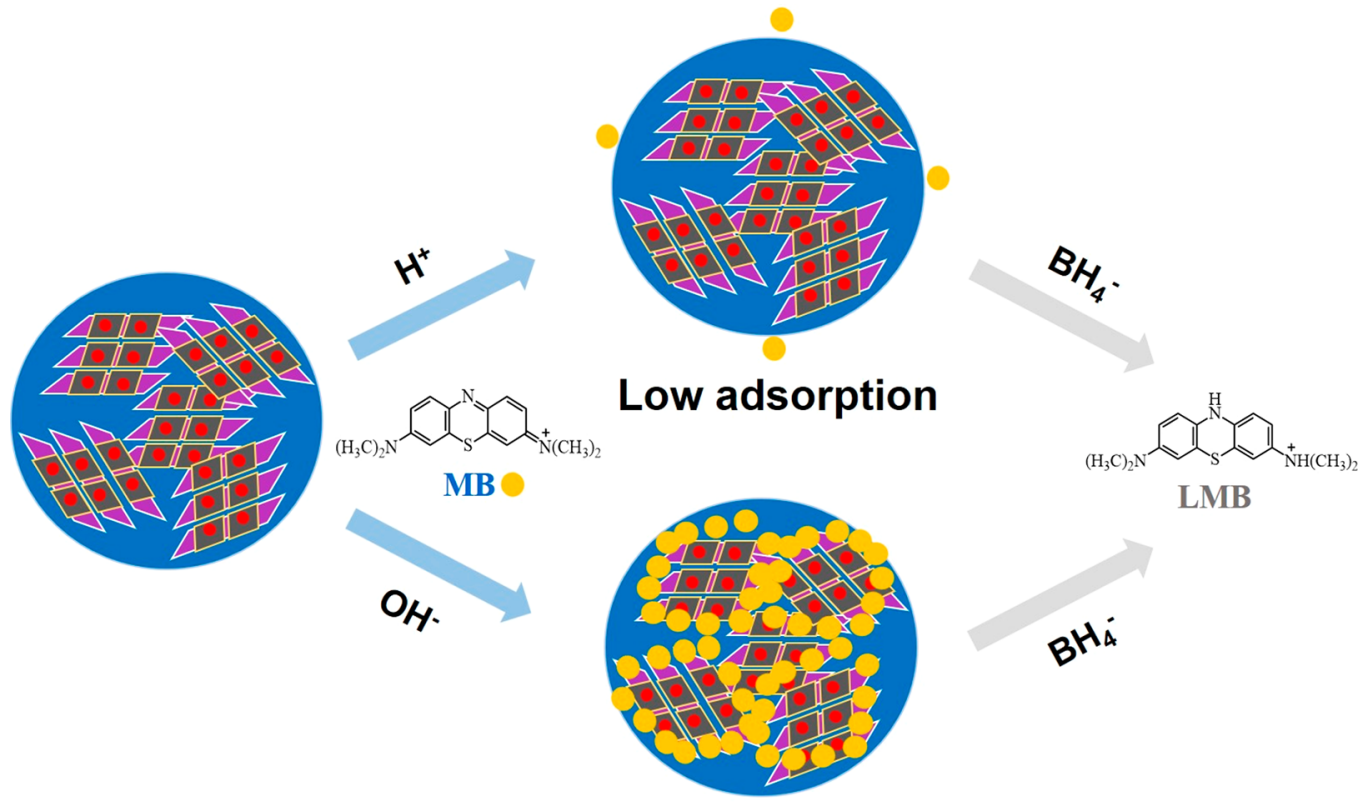

High adsorption

Figure 6. Proposed mechanism of the catalytic reduction of $\mathrm{MB}$ at low and high $\mathrm{pH}$ values.
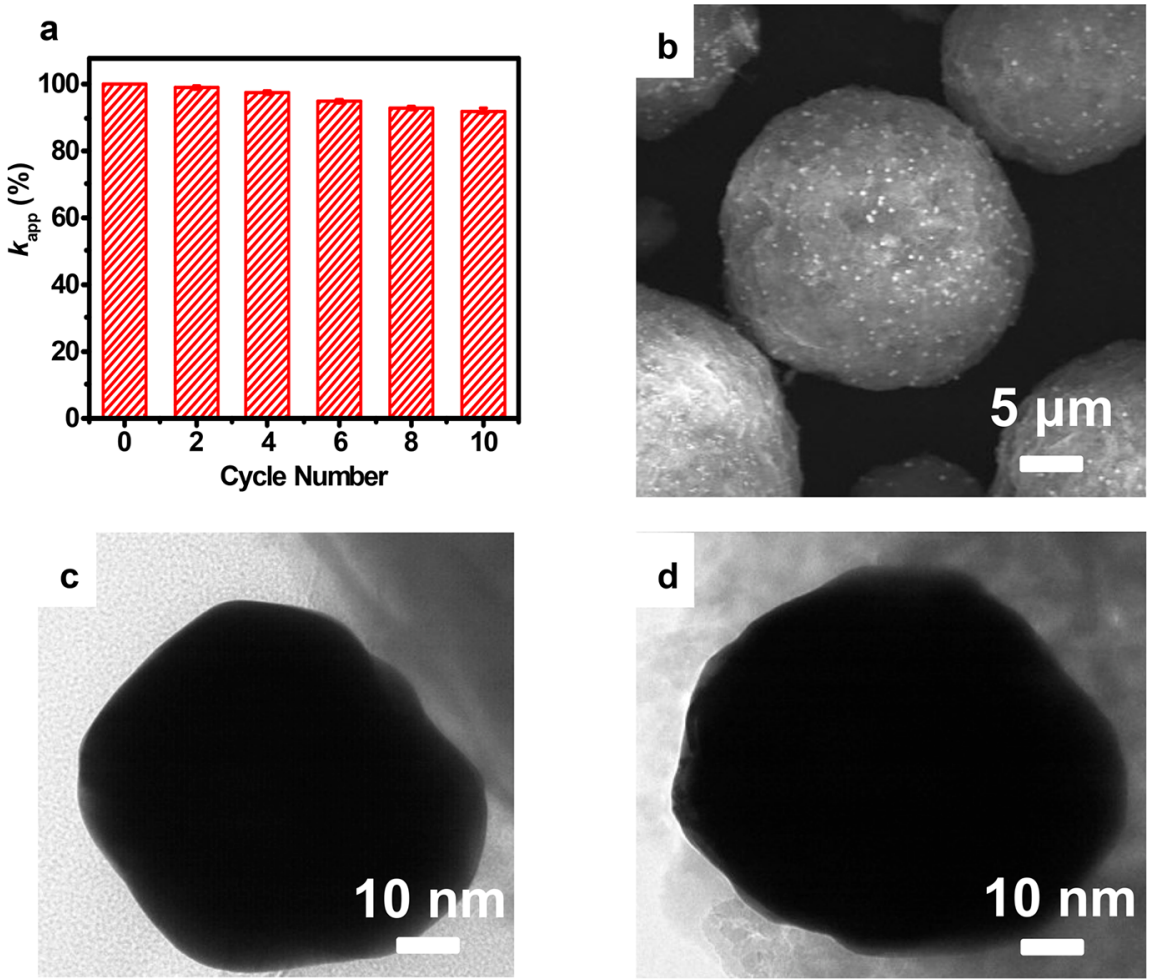

Figure 7. (a) Recyclability of SMt/g- $\mathrm{C}_{3} \mathrm{~N}_{4} / \mathrm{Au}$ NPs in the reduction of MB. (b) SEM image of SMt/g-C $\mathrm{N}_{4} / \mathrm{Au}$ NPs. TEM images of (c) fresh and (d) $\mathrm{SMt} / \mathrm{g}-\mathrm{C}_{3} \mathrm{~N}_{4} / \mathrm{Au}$ NPs heterostructures after 10 cycles.

on SMt due to the adhesion of polydopamine (Figure $7 b-d$ ). On the other hand, the $3 \mathrm{D}$ microsized heterostructures can be easy recovered from the mixture through the self-sedimentary property without any devices involved. Furthermore, the Au content of the catalysts after recycling 10 times was calculated by ICP-MS, and a value of $2.7 \mathrm{wt} \%$ was obtained, which is consistent with the result of fresh SMt/g- $\mathrm{C}_{3} \mathrm{~N}_{4} / \mathrm{Au} \mathrm{NPs}$. All of these results prove the excellent recyclability of the synthesized $\mathrm{SMt} / \mathrm{g}-\mathrm{C}_{3} \mathrm{~N}_{4} / \mathrm{Au}$ NPs heterostructures.

3.6. Practical Application of Porous $S M t / g-C_{3} N_{4} / A u$ NPs Heterostructures. Seawater from the Yellow Sea, Yantai, Shandong Province, China, was used to prove the feasibility of the prepared heterostructures for real applications. After the sand settled down at the bottom of the beaker, $10 \mathrm{~mL}$ of a MB aqueous solution $\left(250 \mathrm{mg} \cdot \mathrm{L}^{-1}\right)$ and $10 \mathrm{~mL}$ of a $\mathrm{NaBH}_{4}$ 


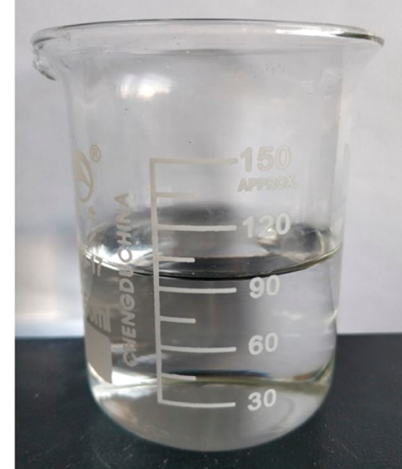

Seawater

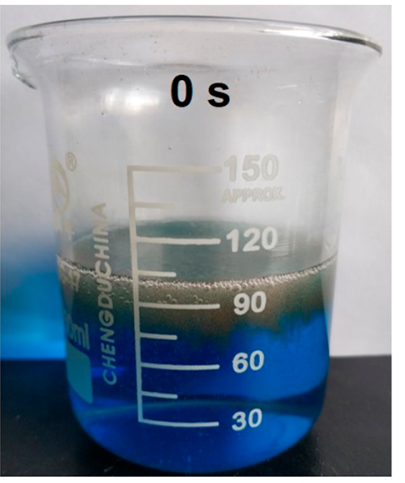

Seawater-MB-NaBH $4^{-}$ $\mathrm{SMt} / \mathrm{g}-\mathrm{C}_{3} \mathrm{~N}_{4} / \mathrm{Au} \mathrm{NPs}$

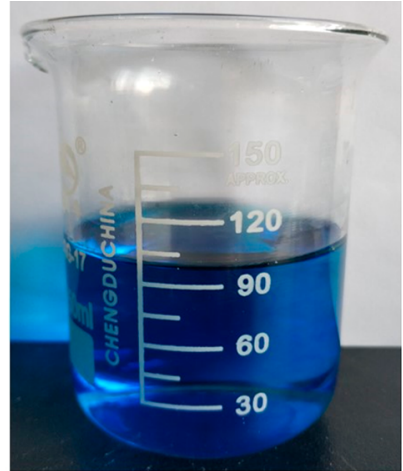

Seawater with MB

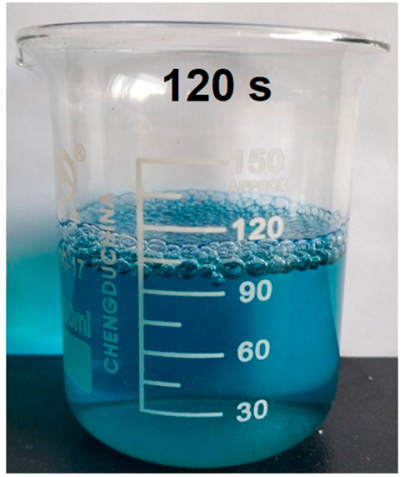

Seawater-MB-NaBH ${ }_{4}^{-}$ SMt/g- $\mathrm{C}_{3} \mathrm{~N}_{4} / \mathrm{Au}$ NPS

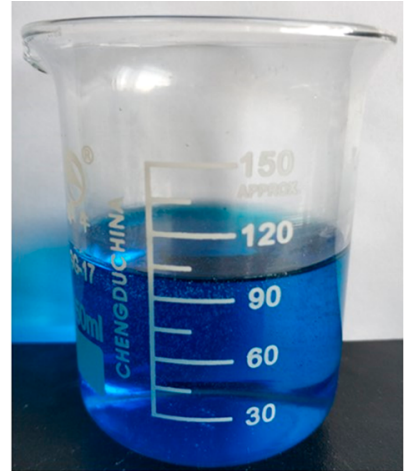

Seawater-MB-NaBH

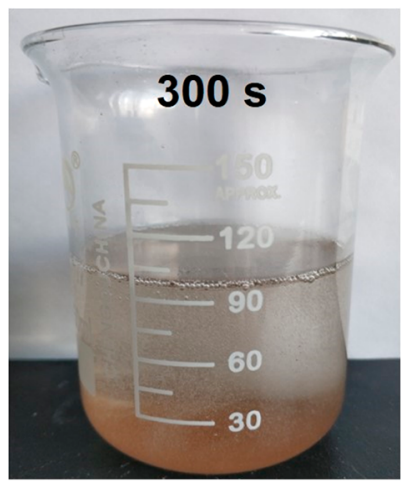

Seawater-MB-NaBH ${ }_{4}^{-}$ SMt/g- $\mathrm{C}_{3} \mathrm{~N}_{4} / \mathrm{Au}$ NPs

Figure 8. Application of synthesized SMt $/ \mathrm{g}-\mathrm{C}_{3} \mathrm{~N}_{4} / \mathrm{Au} \mathrm{NPs}$ for catalytic reduction of $\mathrm{MB}$ in seawater. Reaction conditions: $25 \mathrm{mg} \cdot \mathrm{L}^{-1} \mathrm{MB}, 200 \mathrm{mg}$. $\mathrm{L}^{-1} \mathrm{SMt} / \mathrm{g}-\mathrm{C}_{3} \mathrm{~N}_{4} / \mathrm{Au}$ NPs heterostructures, $0.05 \mathrm{M} \mathrm{NaBH}_{4}, \mathrm{pH} 7, \mathrm{~T}=25^{\circ} \mathrm{C}$.

aqueous solution $(0.5 \mathrm{M})$ were added to the clear seawater $(80$ $\mathrm{mL}$ ). As shown in Figure 8, the bright-blue color of the mixture became light blue within $2 \mathrm{~min}$, while the solution became colorless after $5 \mathrm{~min}$. As can be seen, at the end of the reaction, the synthesized $\mathrm{SMt} / \mathrm{g}-\mathrm{C}_{3} \mathrm{~N}_{4} / \mathrm{Au} \mathrm{NPs}$ heterostructures had already settled down at the bottom of the vessel. Hence, these results prove the applicability of the synthesized heterostructures for the fast and efficient treatment of real wastewaters.

\section{CONCLUSIONS}

In conclusion, 3D porous $\mathrm{SMt} / \mathrm{g}-\mathrm{C}_{3} \mathrm{~N}_{4} / \mathrm{Au}$ NPs heterostructures were synthesized using SMt as the substrate to support exfoliated $\mathrm{g}-\mathrm{C}_{3} \mathrm{~N}_{4}$ nanosheets and Au NPs through polydopamine chemistry. The synthesized SMt/g- $\mathrm{C}_{3} \mathrm{~N}_{4} / \mathrm{Au}$ NPs heterostructures exhibited a universal catalytic activity toward three organic dyes- $\mathrm{MB}, \mathrm{CR}$, and $\mathrm{R} 6 \mathrm{G}$ - under neutral $\mathrm{pH}$ and $25{ }^{\circ} \mathrm{C}$. The catalytic rate would accelerate under alkaline conditions, high temperature, and high $\mathrm{SMt} / \mathrm{g}-\mathrm{C}_{3} \mathrm{~N}_{4} / \mathrm{Au} \mathrm{NPs}$ concentration. For example, the reaction rate was higher $\left(k_{\text {app }}\right.$ $\left.=5.91 \mathrm{~min}^{-1}\right)$ under alkaline conditions $(\mathrm{pH} 11)$, high temperature $\left(35{ }^{\circ} \mathrm{C}\right)$, and high $\mathrm{SMt} / \mathrm{g}-\mathrm{C}_{3} \mathrm{~N}_{4} / \mathrm{Au}$ NPs concentration $\left(250 \mathrm{mg} \cdot \mathrm{L}^{-1}\right)$. The influence of the $\mathrm{pH}$ value on the catalytic performance was systematically investigated. The reason can be attributed to the increased adsorption ability of $\mathrm{SMt} / \mathrm{g}-\mathrm{C}_{3} \mathrm{~N}_{4} / \mathrm{Au} \mathrm{NPs}$ heterostructures toward organic dyes for fast electron transfer from $\mathrm{NaBH}_{4}$ to organic dyes. Furthermore, the synthesized 3D heterostructures proved to be stable and could be easily recovered and reused 10 times with almost unchanged $k_{\text {app }}$. Our strategy used herein to prepare g- $\mathrm{C}_{3} \mathrm{~N}_{4}$ nanosheets-based multifunctional materials with high catalytic performance may extend to other composite systems designed for catalytic applications in wastewater treatment, medical chemistry, and energy storage.

\section{ASSOCIATED CONTENT}

SI Supporting Information

The Supporting Information is available free of charge at https://pubs.acs.org/doi/10.1021/acsanm.0c01355.

Calibration curves of organic dyes, photographs of synthesized samples, $\mathrm{N}_{2}$ adsorption curve of $\mathrm{Mt}$, timeresolved $\mathrm{UV}-$ vis spectra of $\mathrm{MB}$ catalyzed by $\mathrm{SMt}, \mathrm{SMt} /$ g- $\mathrm{C}_{3} \mathrm{~N}_{4}$, and $\mathrm{SMt} / \mathrm{Au} \mathrm{NPs}$, plot of $\ln \left(C_{\mathrm{t}} / C_{0}\right)$ versus reaction time, and photographs of catalytic processes (PDF)

\section{AUTHOR INFORMATION}

\section{Corresponding Authors}

Yawei Qin - Institute of Chemistry, Chinese Academy of Sciences, Beijing 100190, P. R. China; 이이이.org/00000002-2133-8313; Email: ywqin@iccas.ac.cn

Ning Wang - CAS Key Laboratory of Coastal Environmental Processes and Ecological Remediation, Research Center for Coastal Environmental Engineering and Technology of Shandong Province, Shandong Key Laboratory of Coastal Environmental Processes, and Yantai Institute of Coastal Zone Research (YICCAS) and Center for Ocean Mega-Science, Chinese Academy of Sciences, Yantai, Shandong Province 
264003, P. R. China; (1) orcid.org/0000-0001-7590-7801; Phone: +86-535-2109237; Email: nwang@yic.ac.cn

\section{Authors}

Peiqing Zhang - Yantai University, Yantai, Shandong Province 264005, P. R. China; (1) orcid.org/0000-0002-5729-4869

Fushuai Wang - Yantai University, Yantai, Shandong Province 264005, P. R. China; CAS Key Laboratory of Coastal Environmental Processes and Ecological Remediation, Research Center for Coastal Environmental Engineering and Technology of Shandong Province, Shandong Key Laboratory of Coastal Environmental Processes, and Yantai Institute of Coastal Zone Research (YICCAS), Chinese Academy of Sciences, Yantai, Shandong Province 264003, P. R. China; () orcid.org/00000002-3347-7134

Complete contact information is available at:

https://pubs.acs.org/10.1021/acsanm.0c01355

\section{Author Contributions}

All authors have given approval to the final version of the manuscript.

Notes

The authors declare no competing financial interest.

\section{ACKNOWLEDGMENTS}

The authors gratefully acknowledge funding support from the National Natural Science Foundation of China (Grant 51903247), Key Science and Technology Program of Yantai City (Grant 2018ZHGY075), and Shandong Key Laboratory of Coastal Environmental Processes, YICCAS (Grant 2019SDHADKFJJ15), and MogoEdit for their language editing service.

\section{REFERENCES}

(1) Schrinner, M.; Ballauff, M.; Talmon, Y.; Kauffmann, Y.; Thun, J.; Möller, M.; Breu, J. Single Nanocrystals of Platinum Prepared by Partial Dissolution of Au-Pt Nanoalloys. Science 2009, 323, 617-620.

(2) Wang, D.; Astruc, D. Fast-growing Field of Magnetically Recyclable Nanocatalysts. Chem. Rev. 2014, 114, 6949-6985.

(3) Xiong, Z.; Zhang, H.; Zhang, W.; Lai, B.; Yao, G. Removal of Nitrophenols and their Derivatives by Chemical Redox: A Review. Chem. Eng. J. 2019, 359, 13-31.

(4) Seselj, N.; Engelbrekt, C.; Ding, Y.; Hjuler, H. A.; Ulstrup, J.; Zhang, J. Tailored Electron Transfer Pathways in Aucore/PtshellGraphene Nanocatalysts for Fuel Cells. Adv. Energy Mater. 2018, 8, 1702609.

(5) Ray, C.; Pal, T. Recent Advances of Metal-Metal Oxide Nanocomposites and their Tailored Nanostructures in Numerous Catalytic Applications. J. Mater. Chem. A 2017, 5, 9465-9487.

(6) Iqbal, K.; Iqbal, A.; Kirillov, A. M.; Shan, C.; Liu, W.; Tang, Y. A New Multicomponent CDs/Ag@Mg-Al-Ce-LDH Nanocatalyst for Highly Efficient Degradation of Organic Water Pollutants. J. Mater. Chem. A 2018, 6, 4515-4524.

(7) Chaplin, B. P.; Reinhard, M.; Schneider, W. F.; Schüth, C.; Shapley, J. R.; Strathmann, T. J.; Werth, C. J. Critical Review of PdBased Catalytic Treatment of Priority Contaminants in Water. Environ. Sci. Technol. 2012, 46, 3655-3670.

(8) Crooks, R. M.; Zhao, M.; Sun, L.; Chechik, V.; Yeung, L. K. Dendrimer-Encapsulated Metal Nanoparticles: Synthesis, Characterization, and Applications to Catalysis. Acc. Chem. Res. 2001, 34, 181190.

(9) Xiao, F.; Ren, H.; Zhou, H.; Wang, H.; Wang, N.; Pan, D. Porous Montmorillonite@Graphene Oxide@Au Nanoparticle Composite Microspheres for Organic Dye Degradation. ACS Appl. Nano Mater. 2019, 2, 5420-5429.
(10) Jeon, E. K.; Seo, E.; Lee, E.; Lee, W.; Um, M. K.; Kim, B. S. Mussel-Inspired Green Synthesis of Silver Nanoparticles on Graphene Oxide Nanosheets for Enhanced Catalytic Applications. Chem. Commun. 2013, 49, 3392-3394.

(11) Han, Y. Y.; Lu, X. L.; Tang, S. F.; Yin, X. P.; Wei, Z.-W.; Lu, T. B. Metal-Free 2D/2D Heterojunction of Graphitic Carbon Nitride/ Graphdiyne for Improving the Hole Mobility of Graphitic Carbon Nitride. Adv. Energy Mater. 2018, 8, 1702992.

(12) Zhao, D.; Dong, C.-L.; Wang, B.; Chen, C.; Huang, Y.-C.; Diao, Z.; Li, S.; Guo, L.; Shen, S. Synergy of Dopants and Defects in Graphitic Carbon Nitride with Exceptionally Modulated Band Structures for Efficient Photocatalytic Oxygen Evolution. Adv. Mater. 2019, 31, 1903545.

(13) Xiao, W.; Zhang, Y.; Liu, B. Raspberrylike $\mathrm{SiO}_{2} @$ reduced graphene oxide@AgNP Composite Microspheres with High Aqueous Dispersity and Excellent Catalytic Activity. ACS Appl. Mater. Interfaces 2015, 7, 6041-6046.

(14) Xie, Y.; Yan, B.; Xu, H.; Chen, J.; Liu, Q.; Deng, Y.; Zeng, H. Highly Regenerable Mussel-inspired $\mathrm{Fe}_{3} \mathrm{O}_{4} @$ polydopamine-Ag Core-Shell Microspheres as Catalyst and Adsorbent for Methylene Blue Removal. ACS Appl. Mater. Interfaces 2014, 6, 8845-8852.

(15) Godwin, M. A.; Mahithashri, K.; Shiney, O. J. Ultrathin Graphitic Carbon Nitride $\left(\mathrm{g}-\mathrm{C}_{3} \mathrm{~N}_{4}\right)$ Nanosheets: A Novel Solar Reflective Pigment. Adv. Sci., Eng. Med. 2017, 9, 731-735.

(16) Zhuang, Y. T.; Zhu, T. T.; Ruan, M.; Yu, Y. L.; Wang, J. H. A 2D Porous $\mathrm{Fe}_{2} \mathrm{O}_{3} /$ Graphitic- $\mathrm{C}_{3} \mathrm{~N}_{4} /$ Graphene Ternary Nanocomposite with Multifunctions of Catalytic Hydrogenation, Chromium(VI) Adsorption and Detoxification. J. Mater. Chem. A 2017, 5, 34473455.

(17) Ji, H.; Chang, F.; Hu, X.; Qin, W.; Shen, J. Photocatalytic Degradation of 2,4,6-trichlorophenol over g- $\mathrm{C}_{3} \mathrm{~N}_{4}$ under Visible Light Irradiation. Chem. Eng. J. 2013, 218, 183-190.

(18) Zeng, D.; Zhou, T.; Ong, W. J.; Wu, M.; Duan, X.; Xu, W.; Chen, Y.; Zhu, Y. A.; Peng, D. L. Sub-5 nm Ultra-Fine FeP Nanodots as Efficient Co-Catalysts Modified Porous g- $\mathrm{C}_{3} \mathrm{~N}_{4}$ for Precious-MetalFree Photocatalytic Hydrogen Evolution under Visible Light. ACS Appl. Mater. Interfaces 2019, 11, 5651-5660.

(19) Ong, W. J. 2D/2D Graphitic Carbon Nitride $\left(g-\mathrm{C}_{3} \mathrm{~N}_{4}\right)$ Heterojunction Nanocomposites for Photocatalysis: Why Does Face-to-Face Interface Matter? Front. Mater. 2017, 4, 11.

(20) Yang, S.; Gong, Y.; Zhang, J.; Zhan, L.; Ma, L.; Fang, Z.; Vajtai, R.; Wang, X.; Ajayan, P. M. Exfoliated Graphitic Carbon Nitride Nanosheets as Efficient Catalysts for Hydrogen Evolution Under Visible Light. Adv. Mater. 2013, 25, 2452-2456.

(21) Mitra, A.; Howli, P.; Sen, D.; Das, B.; Chattopadhyay, K. K. $\mathrm{Cu}_{2} \mathrm{O} / \mathrm{g}-\mathrm{C}_{3} \mathrm{~N}_{4}$ Nanocomposites: An Insight into the Band Structure Tuning and Catalytic Efficiencies. Nanoscale 2016, 8, 19099-19109.

(22) Coleman, J. N.; et al. Two-Dimensional Nanosheets Produced by Liquid Exfoliation of Layered Materials. Science 2011, 331, 568571 .

(23) He, F.; Li, K.; Yin, C.; Wang, Y.; Tang, H.; Wu, Z. Single Pd Atoms Supported by Graphitic Carbon Nitride, a Potential Oxygen Reduction Reaction Catalyst From Theoretical Perspective. Carbon 2017, 114, 619-627.

(24) Yang, L.; Bai, X.; Shi, J.; Du, X.; Xu, L.; Jin, P. Quasi-FullVisible-Light Absorption by $\mathrm{D} 35-\mathrm{TiO}_{2} / \mathrm{g}-\mathrm{C}_{3} \mathrm{~N}_{4}$ for Synergistic Persulfate Activation towards Efficient Photodegradation of Micropollutants. Appl. Catal., B 2019, 256, 117759.

(25) Chu, J.; Han, X.; Yu, Z.; Du, Y.; Song, B.; Xu, P. Highly Efficient Visible-Light-Driven Photocatalytic Hydrogen Production on CdS $/ \mathrm{Cu}_{7} \mathrm{~S}_{4} / \mathrm{g}-\mathrm{C}_{3} \mathrm{~N}_{4}$ Ternary Heterostructures. ACS Appl. Mater. Interfaces 2018, 10, 20404-20411.

(26) Zhang, Z.; Jiang, D.; Li, D.; He, M.; Chen, M. Construction of $\mathrm{SnNb}_{2} \mathrm{O}_{6}$ Nanosheet/g- $\mathrm{C}_{3} \mathrm{~N}_{4}$ Nanosheet Two-Dimensional Heterostructures with Improved Photocatalytic Activity: Synergistic Effect and Mechanism Insight. Appl. Catal., B 2016, 183, 113-123.

(27) Qin, Y.; Wang, N.; Zhou, Y.; Huang, Y.; Niu, H.; Dong, J. Y. Fabrication of Nanofillers into a Granular "Nanosupport" for Ziegler- 
Natta Catalysts: Towards Scalable in situ Preparation of Polyolefin Nanocomposites. Macromol. Rapid Commun. 2011, 32, 1052-1059.

(28) Wang, N.; Xiao, F.; Zhang, J.; Zhou, H.; Qin, Y.; Pan, D. Spherical Montmorillonite-Supported Nano-Silver as a Self-Sedimentary Catalyst for Methylene Blue Removal. Appl. Clay Sci. 2019, 174, $146-151$.

(29) Xiao, F.; Qin, Y.; Wang, N.; Pan, D. Towards Mass Production of Au Nanoparticles Supported on Montmorillonite Microspheres for Catalytic Reduction of 4-nitrophenol. Appl. Clay Sci. 2018, 166, 7479.

(30) Wang, N.; Hu, Y.; Zhang, Z. Sustainable Catalytic Properties of Silver Nanoparticles Supported Montmorillonite for Highly Efficient Recyclable Reduction of Methylene Blue. Appl. Clay Sci. 2017, 150, 47-55.

(31) Besner, S. B.; Meunier, M. Femtosecond Laser Synthesis of AuAg Nanoalloys: Photoinduced Oxidation and Ions Release. J. Phys. Chem. C 2010, 114, 10403-10409.

(32) Wang, N.; Zhang, Z.; Huang, J.; Hu, Y. Facile Synthesis of Copper Ions Chelated Sand via Dopamine Chemistry for Recyclable and Sustainable Catalysis. Chem. Eng. Sci. 2019, 203, 312-320.

(33) Subair, R.; Tripathi, B. P.; Formanek, P.; Simon, F.; Uhlmann, P.; Stamm, M. Polydopamine Modified Membranes with in situ Synthesized Gold Nanoparticles for Catalytic and Environmental Applications. Chem. Eng. J. 2016, 295, 358-369.

(34) Zeng, T.; Niu, H. Y.; Ma, Y. R.; Li, W. H.; Cai, Y. Q.; Zhang, X. L. In situ Growth of Gold Nanoparticles onto PolydopamineEncapsulated Magnetic Microspheres for Catalytic Reduction of Nitrobenzene. Appl. Catal., B 2013, 134-135, 26-33.

(35) Nabil, B.; Ahmida, E. A.; Christine, C.; Julien, V.; Abdelkrim, A. Polyfunctional Cotton Fabrics with Catalytic Activity and Antibacterial Capacity. Chem. Eng. J. 2018, 351, 328-339.

(36) Ganapuram, B. R.; Alle, M.; Dadigala, R.; Dasari, A.; Maragoni, V.; Guttena, V. Catalytic reduction of methylene blue and Congo red dyes using green synthesized gold nanoparticles capped by salmalia malabarica gum. Int. Nano Lett. 2015, 5, 215-222.

(37) Shen, H.; Duan, C.; Guo, J.; Zhao, N.; Xu, J. Facile in situ Synthesis of Silver Nanoparticles on Boron Nitride Nanosheets with Enhanced Catalytic Performance. J. Mater. Chem. A 2015, 3, 1666316669 .

(38) Ingersoll, J. C.; Mani, N.; Thenmozhiyal, J. C.; Muthaiah, A. Catalytic Hydrolysis of Sodium Borohydride by a Novel NickelCobalt-Boride Catalyst. J. Power Sources 2007, 173, 450-457.

(39) Hu, J.; Dong, Y. L.; Rahman, Z. U.; Ma, Y. H.; Ren, C. L.; Chen, X. G. In situ Preparation of Core-satellites Nanostructural Magnetic-Au NPs Composite for Catalytic Degradation of Organic Contaminants. Chem. Eng. J. 2014, 254, 514-523.

(40) Iqbal, K.; Iqbal, A.; Kirillov, A. M.; Wang, B.; Liu, W. S.; Tang, Y. New Ce-Doped MgAl-LDH@Au Nanocatalyst for Highly Efficient Reductive Degradation of Organic Contaminants. J. Mater. Chem. A 2017, 5, 6716-6724.

(41) Usher, A.; McPhail, D. C.; Brugger, J. A. A Spectrophotometric Study of Aqueous $\mathrm{Au}$ (III) Halide-hydroxide Complexes at $25-80{ }^{\circ} \mathrm{C}$. Geochim. Cosmochim. Acta 2009, 73, 3359-3380.

(42) Nayak, A. K.; Pal, A. Rapid and High-performance Adsorptive Removal of Hazardous Acridine Orange from Aqueous Environment using Abelmoschus Esculentus Seed Powder: Single- and Multiparameter Optimization Studies. J. Environ. Manage. 2018, 217, 573591.

(43) Ghosh, U.; Pal, A. Graphitic Carbon Nitride based Z Scheme Photocatalysts: Design Considerations, Synthesis, Characterization and Applications. J. Ind. Eng. Chem. 2019, 79, 383-408.

(44) Biswas, S.; Pal, A. Visible Light Assisted Fenton Type Degradation of Methylene Blue by Admicelle Anchored Alumina Supported Rod Shaped Manganese Oxide. J. Water Process Eng. 2020, 36, 101272. 